\title{
Style and Emulation in the Renaissance of New Spain
}

Author: Lauren Hirsch

Faculty Mentor: Kelly Donahue-Wallace

Department and College Affiliation: Department of Art Education and Art History, College of Visual Arts and Design 


\section{Bio:}

Lauren Hirsch is a senior at the University of North Texas in the College of Visual Arts and Design. She is completing degrees in Art History and Printmaking, with a minor in French. Hirsch is head of Community Outreach in the department's Art History Society and in charge of art show coordination for the Printmaking Association of North Texas Students (PANTS). She also works for the circulation department in the school's libraries. This fall, Lauren's paper won the University Undergraduate Award for 2009. After completing her undergraduate degrees, Hirsch hopes to find employment through the French Embassy teaching English in Europe until she can focus all of her interests into a specific course of graduate study. 


\begin{abstract}
:
The following paper explores the relationship between artwork created during the Renaissance in Italy and in New Spain 150 years later. Simon Pereyns’ Virgen del Pardon and Raphael’s La Belle Jardinière are explored through visual, as well as contextual, analyses to provide evidence for a connection between the two works that is more significant than a similarity of figurative content alone. It was Raphael who helped to establish the Italian Renaissance tradition and artists like Pereyns who attempted to recreate the style and effect for their own purposes. The research on the artworks serves to show that socially and politically, the work of Pereyns and Raphael served similar purposes for the church, as well as the crown.
\end{abstract}




\section{Introduction}

Though the Renaissance in Italy preceded that in New Spain by almost 150 years, numerous associations can be made between the political and social events of each country and between the modes employed to achieve the basic goals associated with the creation of art in each setting. As an artist representing the Italian High Renaissance, Raphael worked in a western style, using his art to communicate the perfect beauty of man. Simon Pereyns, a European hailing from the North, immigrated to New Spain and produced art in this new environment that melded Flemish and Italian elements to suit the needs of his patrons. A visual and contextual analysis of Raphael's La Belle Jardinière and Simon Pereyns' Virgen del Pardon reveals that the connection between these two works is not simply content-based, but that a strong relationship exists between the patronage and the social and religious contexts in which these works were created.

The Renaissance in Italy was a marked break from Medieval beliefs in favor of a worldview more dominated by humanism and the perfectibility of man (Ruskin 11). By revisiting art and literature from antiquity, a new order for the future was formed. The discovery of ancient statuary gave artists a reference from which to work and helped them to successfully merge classical antiquity with Christianity. These humanistic tendencies not only made reconciliation possible, but also influenced the elevation of the working artist to the level of a creative genius (Hale 35). Thus, the artist often used his work as an exercise in exploring the beauty of man and nature, using a religious context for the benefit of the patron (Ruskin 11).

\section{Raphael}

Born in Urbino in 1483, Raphael's youth was filled with the study and creation of art, but he was taught primarily through an apprenticeship to Pietro Perugino, a painter known for creating religious images backed by landscapes of Perugia (Ruskin 40). Raphael looked to other 
working artists of the time, diligently studying popular styles and compositions to increase his understanding of art- making (Ruskin 40). Working as an artist, but continually learning from his contemporaries, Raphael gained his reputation as a storyteller and a painter of beautiful Madonnas (Nasso 39). He worked in a gradated style, using classical imagery in a modern context, giving new meaning to a visual language (Nasso 57). His imitation and transformation of Roman molds mixed spiritual and vernacular sensibilities to create work acceptable to patrons that also functioned as exercises in the portrayal of natural beauty.

Raphael's La Belle Jardinière reflects the study and interpretation of works by master artists. Both Leonardo da Vinci and Michelangelo Buonarroti provided important contemporary models from which Raphael worked. Raphael uses a studied casualness, pyramidal composition, and sfumato technique employed by Da Vinci, though he adapts these practices for his purposes. Similarly, Raphael learned from Michelangelo, laboring to produce his famous nudes at a new level of mastery (Ruskin 40). Raphael achieves a unified naturalistic composition that uses rich and luminous color to create a more sensitive portrayal of light and shadow than had been previously achieved in two-dimensional art. He successfully uses a broad range of colors and tints to communicate a beautiful and gentle spiritual world in La Belle Jardinière that echoes Perugino’s spacious landscape settings. To his benefit, Raphael moves past reproducing work of other artists and adapts certain techniques to better suit his work and define his style.

Created in 1507, La Belle Jardinière depicts the Virgin Mary and infants, Jesus and John the Baptist. The work employs the classic pyramidal composition that is simple, yet balanced and captivating. To counter the geometric composition, Raphael has used graceful colors, sensitive shadows and flowing drapery to add visual layers (Nasso 31). The gestures of the figures imply a discourse that creates a sense of unifying intimacy. Though seemingly at play with John, Jesus 
shares a tender bond with the idealized Madonna. This knowing glance in the eyes of the Virgin contrasts with the youthful innocence of the infants and allows the viewer to feel part of an important Biblical moment (Béguin 30). In this piece, Raphael has melded light and shadow in such a way that his figures are highly realistic, almost to the point of appearing sculptural. Overall, he allows this work to unite Northern Italian disegno and historia with Venetian colorito to appeal to both patron and viewer (Hale 36).

The narrative clues of La Belle Jardinière are key to the understanding of the work. The positioning of the figures serves as a prefiguration of the Passion and Christ's eventual death. The Virgin Mary occupies the matriarchal spot, and the book she holds announces the inevitable sacrifice of her son. John is in a supportive position, kneeling in service, holding the cross of sacrifice, and regarding Jesus with eyes filled with love and compassion (Ruskin 43). The infant Jesus regards his mother intently as she remains calm and loving. This exchange of glances narrates the ultimate happy moment prior to the revelation of what the life of Jesus will bring. Raphael's work successfully combines concrete religious iconography with an exercise in vernacular beauty to fulfill both the goals of humanism and those of the Catholic patron (Rowland 203).

The Spanish Conquest of 1519 marked the start of the Viceregal Era of New Spain and the attempt of the Spanish crown to both strengthen and expand its empire (Bantel 9). After the late 1500s, the initial attempts at converting natives were abandoned in order to focus on the elevation of the status of Spain's colony in the New World. Often through art, Spain would attempt to communicate the power of its empire, as well as legitimize the worth of the growing colony. The high cultural and intellectual authority, equated with the Italian Renaissance, dictated that art created in New Spain would closely mirror the style and methods of European 
art to emphatically draw parallels between the two realms (Burke 17). The conquest of Mexico began a new timeline that lagged slightly behind that of Europe. Thus, while Mannerism was decreasing in popularity in Italy, there was a tendency to continue working in this style in New Spain. However, the 1945 Council of Trent dictated that the extreme artificial qualities typical of Mannerism would be softened to achieve pure, narrative clarity, to increase piety, and to reduce confusion (O’Neill 287). The immigration of European artists and the importation of European art to New Spain helped the ideals of Renaissance humanism to persist in the extended Spanish empire (Fane 28). However, the number of painted works brought to New Spain was limited and more often than not, the printed, single-leaf image was used to disseminate copies of masterpieces, as well as ideas of European style (Fane 32). Engraved and printed in the Netherlands under the Spanish crown, these works were then shipped to Mexico from Seville (Burke 31). Initially, these prints were used to teach indigenous peoples, but were later referenced by European artists looking to emulate the Renaissance style.

\section{Simon Pereyns}

Born in Antwerp, Simon Pereyns was a first generation Mannerist with a natural Flemish approach to art and a unique reformed Mannerist style (Rishel 25). Pereyns had an active career around Spain as a portrait painter with frequent royal patronage. In Madrid, Pereyns met the Marqués de Falces, don Gastón de Peralta who was about to leave for New Spain to serve as Viceroy. Peralta offered to take Pereyns as part of his personal staff and the group arrived in Viceregal Spain in 1566 (Rishel 325). Pereyns accepted, in hopes that he could escape the rising competition in Europe and find more artistic success. Once in New Spain, Pereyns completed paintings in Peralta’s palace, as retablos in various missions. Pereyns was denounced by a rival to the Tribunal de la Fe, the predecessor of the Inquisition in New Spain. The rival stated that the 
Flemish artist was reluctant to paint religious scenes and that his morals were questionable (Rishel 325). Pereyns was tried before the Tribunal and found guilty. As penance, he painted an image of the Virgin Mary that is commonly identified as the 1599 Virgen del Pardon. It was installed in the Mexico City Cathedral but destroyed in a fire in 1967 (Fane 31).

The work itself depicts the Virgin Mary holding the Christ child on a throne, elevated above Joseph and an unidentified female saint, most likely the Virgin’s mother, Anne. Angels, drapery, and classical architecture flank the scene and indicate the importance of the figures depicted. Pereyns’ work as a northern Mannerist painter influenced his compositions, and this work is no exception. The work uses primarily light-shot, slightly acidic colors to depict elongated and distorted figures whose disturbed faces and gestures are crowded into a close picture plane (Carerra 30). The use of chiaroscuro, modeling, and one-point perspective seen in the tiles of the floor reflect a Central European influence. The pyramidal composition is extremely reminiscent of Raphael's work and the overt use of symbols is also typical of Italian High Renaissance art. Raphael's work, Madonna of Foligno (1511-1512) was the source of inspiration for Pereyns’ depiction of the Madonna and baby Jesus. In attempting to work in the style of a divine artist, Pereyns consulted visual aids that were circulating around Mexico at the time. Pereyns most likely saw Raphael’s Madonna as a single-leaf print, which explains the translated appearance of the figures in the later work.

Pereyns’ Virgen del Pardon, like many other artists’ work at the time, was a direct result of patronage (Bargellini 50). The subject matter was decidedly religious, due to the circumstances surrounding its creation. However, Pereyns made a choice to paint in the style of Raphael. Seen as the model of divine artistic geniuses, Raphael’s art clearly communicates the humanistic ideals of the Italian Renaissance. Once the evangelizing period of New Spain came to 
a close, the focus of the Spaniards became increasingly Eurocentric. Emulation of Italian Renaissance artists was used in an effort to emphatically state that the viceregal state in the New World was one of equal value to the culturally exclusive areas in Europe. Pereyns' stylistic choices make a statement about both the status of New Spain and his status as a Renaissance artist. Depicting religious subject matter in the style of Italian Renaissance artists facilitated the reputation of Europeans in New Spain as both civilized and sophisticated.

\section{Comparison of Raphael and Pereyns}

Similar in style and subject matter, the works of Raphael and Pereyns are ultimately influenced by religious patronage. In both pieces, the use of European illusionist devices helps the intended audiences to visualize the importance, power, and intellect of the classical style, the church, and ultimately the crown (Peterson 7). Raphael paints as an exercise in depicting earthly beauty, while Pereyns works in an attempt to equate himself to highly regarded Central Italian Artists. Regardless, the pieces both serve to advertise the church as a specialized patron for this type of artwork (Rishel 73). Despite the wishes of the patrons, both works manage to communicate personal style and skill. Upon a visual analysis of the works, it seems that Pereyns' Virgen del Pardon lacks the sense of refinement seen in Raphael's La Belle Jardinière. While Raphael studied nature and master artists in an attempt to duplicate the depictions found in classical works, Pereyns worked from prints, resulting in appropriated work that feels translated and slightly clumsy. The simplified, flattened depiction of figures in Virgen del Pardon echoes the two-dimensional influence from which the artist was working (Rishel 74).

Socially and politically, La Belle Jardinière and Virgen del Pardon served similar purposes. Both works overtly convey the power of the church and, thusly, the power of the crown. Pereyns and Raphael both use appropriation as an important artistic tool in their works. 
However, Raphael developed a personal style that became the standard for High Renaissance art. La Belle Jardinière depicts a cultural sophistication and perfection that became synonymous with the high culture and courtliness of Italy. Pereyns was looking to Raphael's models as the standard, and thus uses appropriation more assertively in Virgen del Pardon. Pereyns models Raphael almost directly in an attempt to equate New Spain with the refined reputation of Italy that was created in part by artists such as Raphael. 
Works Cited

Bantel, Linda, and Marcus B. Burke. Spain and New Spain. Corpus Christi: Art Museum of South Texas, 1979.

Bargellini, Clara, Rogelio Ruiz Gomar, and Donna Pierce. Painting a New World:Mexican Art and Life 1521-1821. Denver: Denver Art Museum, 2004.

Béguin, Sylvie. Les Peintures de Raphael au Louvre. Paris: Editions de la Reunion des Musees Nationaux, 1984.

Burke, Marcus B. Mexican Art Masterpieces. Hong Kong: Hugh Lauter Levin Associate, Inc., 1998.

Carrera, Magali M. Imagining Identity in New Spain: Race, Lineage, and the Colonial Body in Portraiture and Casta Paintings. Austin: University of Texas Press, 2003.

Fane, Diana. Converging Cultures: Art and Identity in Spanish America. New York: Harry N. Abrams, Inc., Publishers, 1996.

Hale, John R. Italian Renaissance Painting: From Masaccio to Titian. New York: E. P. Dutton \& Co., Inc., 1977.

Nasso, Claudio. Raphael: Grace and Beauty. Milano: Skira Editore S.P.A., 2001.

O’Neill, John P. Mexico: Splendors of Thirty Centuries. New York: Bulfinch Press, 1990.

Peterson, Jeanette Favrot. The Paradise Garden Murals of Malinalco: Utopia and Empire in Sixteenth-Century Mexico. Austin: University of Texas Press, 1993.

Rishel, Joseph J. The Arts in Latin America: 1492-1820. Philadelphia: Philadelphia Museum of Art, 2006.

Rowland, Ingrid D. The Culture of the High Renaissance. Cambridge: Cambridge University Press, 1998.

Ruskin, Ariane. Art of the High Renaissance. New York: McGraw-Hill, 1961. 